\author{
Andrzej WIEcCKOWSKI ${ }^{1}$ \\ Roman ZIMKA ${ }^{2}$
}

\title{
ODKSZTAŁCENIA WCZEŚNIE OBCIĄŻONEGO MŁODEGO BETONU NA SZYBKOWIĄŻĄCYM CEMENCIE CSA
}

\begin{abstract}
Cement CSA jest spoiwem mineralnym, hydraulicznym, o szybkim narastaniu wytrzymałości wczesnej, małym skurczu i wysokiej odporności na siarczany. Po zarobieniu cementu CSA wodą następuje szybka reakcja pomiędzy siarczanoglinianem wapnia, gipsem i wodorotlenkiem wapnia, z dynamicznym wydzielaniem ciepła i intensywnym powstawaniem ettringitu, minerału pozwalającego osiągnąć dużą wytrzymałość wczesną. Szybkie uzyskanie wysokich wytrzymałości na ściskanie betonu na cemencie CSA (wynoszących kilkanaście MPa, po 1 godzinie od chwili dodania wody) umożliwia wczesne obciążenie wykonanych elementów. Stąd przedmiotem wstępnych badań było określenie wielkości odkształceń powstających w młodym betonie, przy działającym obciążeniu, już po 1,5h oraz $2 \mathrm{~h}$ od chwili zarobienia składników wodą. W kontekście wyników obliczeń wg Eurokodu stwierdzono, że odkształcenia próbek młodego betonu na CSA, w przypadkach obciążeń $k_{\sigma} \leq 0,45$, nie są większe od wyliczonych na podstawie załączonych w normie wzorów. W przypadku większych obciążeń, przy $k_{\sigma}>0,5$ przy obliczeniach nieliniowego pełzania, odkształcenia po pierwszym dniu przekraczają o około $50 \%$ wartości teoretyczne, a w następnych dniach intensywnie maleją i po 5-tym dniu są mniejsze, niż obliczone wg Eurokodu 2.
\end{abstract}

Słowa kluczowe: cementy siarczanoglinowe, CSA, pełzanie betonu, beton szybkowiążący

\section{Wstęp}

W przypadku zastosowania cementów szybkowiążących istotną cechą jest możliwość wczesnego obciążenia konstrukcji. Beton na cemencie CSA po kilku godzinach od zarobienia mieszanki wodą, dzięki szybkiej reakcji siarczanoglinianu wapnia uzyskuje duże wytrzymałości na ściskanie (nawet ponad $20 \mathrm{MPa}$ ), a pełną wytrzymałość, gwarantowaną przez producenta po 3 do 7 dniach.

\footnotetext{
${ }^{1}$ Autor do korespondencji / corresponding author: Andrzej Więckowski, Akademia Górniczo-Hutnicza im. Stanisława Staszica w Krakowie, Al. A. Mickiewicza 30, 30-059 Kraków, tel. +48126772083, awiecko@agh.edu.pl

${ }^{2}$ Roman Zimka, Państwowa Wyższa Szkoła Zawodowa w Krośnie, Krosno, Rynek 1, tel +48 134364352 , r.zimka@wp.pl
} 
Aby w sposób bezpieczny można było realizować projekty budowane i znacznie wcześniej, niż po 28 dniach obciążać wykonane elementy, konieczne jest dokładne przebadanie tego betonu pod kątem odkształceń związanych z pełzaniem. Również przy naprawach lub przy zastosowaniach specjalnych, niezmiernie ważne jest sprawdzenie zachowania się takiego betonu pod obciążeniem podczas pierwszych godzin po osiągnięciu potrzebnej wytrzymałości na ściskanie. Stąd celem badań jest wstępna ocena odkształceń wcześnie obciążonego młodego betonu na cemencie CSA.

\section{Cementy szybkowiążące}

Cementy portlandzkie o bardzo znaczących walorach wytrzymałościowych, tracą właściwości wiążące przy dłuższym przechowywaniu oraz wykazują skurcz podczas wiązania i wymagają znacznego czasu zaformowania. Prace nad zastosowaniem innego materiału, opartego o cement glinowy były prowadzone, już w latach $30 \mathrm{XX}$ w., m.in. przez Stefana Bryłę [2]. Uzyskane wyniki świadczyły o znacznie lepszych parametrach takiego cementu, z uwagi na: względnie szybki przyrost wytrzymałości, dopuszczalne niższe temperatury betonowania, odporność na korozję siarczanową, długi okres magazynowania i krótki czas zaangażowania urządzeń formujących, lecz okazały się znacznie droższymi.

$\mathrm{W}$ tym samym czasie trwały prace nad ograniczaniem skurczu w betonie. Najlepszą metodą okazało się wykorzystanie wzrostu objętości, który ma miejsce $\mathrm{w}$ procesie powstawania ettringitu. Wzrost ten uzyskiwano poprzez dodawanie do cementu portlandzkiego tlenków glinu. Pierwsze takie próby prowadzone były we Francji, w latach trzydziestych ubiegłego wieku [6]. W 1966 roku w Stanach Zjednoczonych, Alexander Klein zaproponował zastosowanie siarczanoglinianu wapnia, jako źródła jonów glinu, a następnie opatentował technologię wytwarzania betonu bazującego na zmieszanych cementach: portlandzkim i ekspansywnym, opartym o siarczanoglinian wapnia (rys. 1.). Zgodnie z patentem A. Kleina, przy zastosowaniu właściwej proporcji cementów: portlandzkiego do ekspansywnego, efektem był brak rys skurczowych, tak charakterystycznych dla betonów wyłącznie na cemencie portlandzkim.

Dzięki dalszym pracom badawczym przy różnych proporcjach „,w trójkącie materiałów": siarczanoglinian wapnia $\left(4 \mathrm{CaO} \cdot 3 \mathrm{Al}_{2} \mathrm{O}_{3} \cdot \mathrm{SO}_{4}\right)$, gips $\left(\mathrm{CaSO}_{4} \cdot 2 \mathrm{H}_{2} \mathrm{O}\right)$ i krzemian dwuwapniowy $\left(2 \mathrm{CaO} \cdot \mathrm{SiO}_{2}\right)$ wyodrębniono proporcje mieszanek dla cementów szybkowiążących (w pozycji literatury [6] nazwanych cementami szybkotwardniejącymi), ekspansywnych oraz słabo ekspansywnych. Zgodnie z rys. 2., np. przy zastosowaniu względnie mniejszej ilości gipsu uzyskuje się cementy szybkowiążące, w obszarze pola I [6]. W obszarach pól II, III występują cementy odpowiednio, słabo ekspansywne i ekspansywne. 


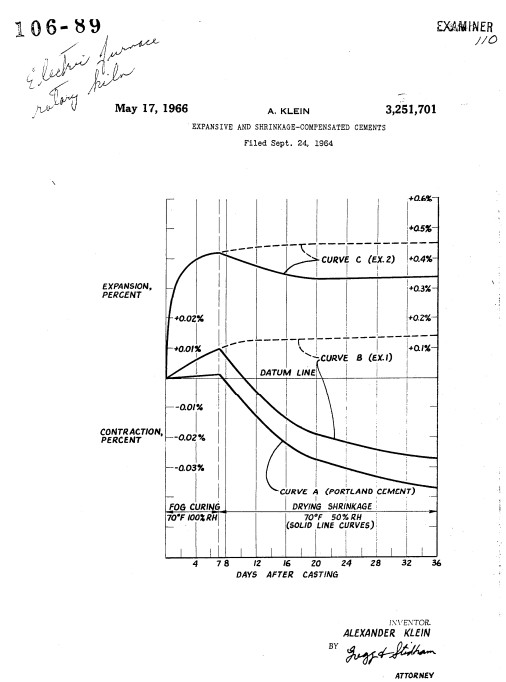

Rys. 1. Zgłoszenie patentowe Kleina - cześć rysunkowa [3]

Fig. 1. Klein patent application - drawing part [3]

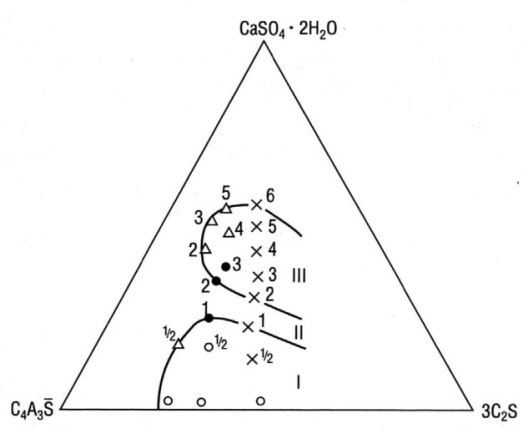

Rys. 2. Wpływ trzech głównych faz na właściwości cementów: I, II, III - obszary pól cementów odpowiednio, szybkowiążących, słabo ekspansywnych, ekspansywnych, na podstawie [6]

Fig. 2. Effect of the three main phases on the cement properties: I, II, III - areas of fields of cement respectively, the fast, low expansive, expansive, based on [6]

Aby uzyskać duże wytrzymałości cementów szybkowiążących, dla klinkieru wypalanego w temperaturze ponad $1200{ }^{\circ} \mathrm{C}$ najkorzystniejsze proporcje glinu do krzemu wynoszą $A / S=2,0 \div 2,5$, przy module nasycenia wapnem $M_{N}=1$ [9]. Prace nad otrzymaniem tego typu cementu prowadzone były również w Polsce, w latach siedemdziesiątych XX wieku, w Instytucie Przemysłu Wiążących Materiałów Budowlanych w Opolu, lecz później zostały zaniechane. Obecnie największymi producentami cementów szybkowiążących są Stany Zjednoczone i Chiny $[5,6,10,13,15,21]$.

\section{Właściwości cementu CSA}

Głównymi składnikami cementów, nazywanych w skrócie CSA, są: bezwodnik siarczanoglinianu wapnia $\left(4 \mathrm{CaO} \cdot 3 \mathrm{Al}_{2} \mathrm{O}_{3} \cdot \mathrm{SO}_{4}\right)$ odpowiadający za wczesny przyrost wytrzymałości, krzemian dwu wapniowy $\left(2 \mathrm{CaO} \cdot \mathrm{SiO}_{2}\right)$ oraz gips $\left(\mathrm{CaSO}_{4} \cdot 2 \mathrm{H}_{2} \mathrm{O}\right)$. Cementy CSA wypala się w temperaturze około $1250^{\circ} \mathrm{C}$, a otrzymany klinkier jest bardziej miękki niż cementu portlandzkiego (który jest wypalany w $1450^{\circ} \mathrm{C}$ ). Dlatego też czasami w literaturze, ze względu na mniejsze zużycie energii potrzebnej do jego produkcji, CSA nazywa się cementem zielonym. Cementy te produkowane są w klasach 42,5, 52,5, 62,5 72,5 82,5 i 92,5 (które w tym przypadku oznaczają wytrzymałości na ściskanie osiągane w ciągu siedmiu dni) a składowane $w$ suchych pomieszczeniach i w nie uszkodzonych opakowaniach mają trwałość 12 miesięcy. 
Zalecana proporcja wody do cementu $w / c$ powinna się zawierać, wg [4] w przedziale $0,41 \div 0,61$, zaś wg [18] w zakresie $0,36 \div 0,65$. Należy zwrócić uwagę, że do uzyskania w reakcji monosiarczanu glinianu wapnia niezbędne jest uzyskanie pełnego nawodnienia, które zachodzi, przy minimalnej proporcji $w / c>0,36[17]$.

Skład kruszywa jest dobierany na podobnych zasadach, jak w betonach zwykłych, przy czym nie jest zalecana mniejsza ilość CSA, niż $300 \mathrm{~kg} / \mathrm{m}^{3} \mathrm{mie}-$ szanki betonowej, [20].

Aby osiągnąć zamierzoną wytrzymałość, przygotowanie i układanie betonu na cemencie CSA powinno obywać się w temperaturze zewnętrznej od $7{ }^{\circ} \mathrm{C}$ do $32{ }^{\circ} \mathrm{C}$ (w niższej temperaturze proces wiązania przebiega znacznie wolniej, natomiast $\mathrm{w}$ wyższej temperaturze, przy dodatkowym cieple wiązania może dochodzić do rozpadu ettringitu). W temperaturze $20{ }^{\circ} \mathrm{C}$ początek wiązania następuje, wg [16] już po 15 minutach, wg [20] po 25 minutach. Stosując, jako opóźniacz kwas cytrynowy można ten czas wydłużyć o 15 minut.

Na podstawie badań próbek betonu na cemencie CSA, z mieszanki 1 Concrete Mix na Rapid Set ${ }^{\circledR}$, o początku wiązania $t_{p w}^{1}=18$ minut, wykonanych zgodnie z EN 196-1, w laboratorium AGH w Krakowie stwierdzono [14]:

- bardzo szybko narastającą wytrzymałość na ściskanie, która po 1 godzinie (od chwili zarobienia wodą) wynosiła nawet $30 \mathrm{MPa}$,

- istotnym zagadnieniem była ilość dozowanej wody; przy zwiększaniu wartości wskaźnika wody do cementu w/c od 0,41 do 0,61, średnie po 1-nej godzinie, wytrzymałości na ściskanie $f_{c \text { ch }}$ zmalały, odpowiednio od 30,1 MPa do 18,1 MPa, tj. o $40 \%$ i podobnie po 2-ch godzinach $f_{c 2 \mathrm{~h}}$ również zmalały, od 36,8 MPa do 22,4 MPa, tj. o około $39 \%$,

- w przypadku mieszanki 2, Concrete Mix z „lekko” opóźnionym początkiem wiązania $t_{p w}^{2}=32$ minuty (bardzo korzystnym wykonawczo) próbki uzyskały wytrzymałości 24,9 MPa i 31,5 MPa, odpowiednio po 1,5 i 4,0 godzinach (od chwili dodania wody), tj. o około 0,5 i poniżej 2 godzin później, niż podobne wytrzymałości 24,5 MPa i 30,0 MPa uzyskały próbki po 1-nej i po 2 godzinach, które były wykonane z mieszanki typowej, o początku wiązania $t_{p w}^{1}=18$ minut.

Dokładny przebieg przemian chemicznych podczas wiązania nie jest dobrze rozpoznany. Przyjmuje się, że w początkowym okresie nawodnienia CSA następuje rozwój $80 \%$ ettringitu, jeszcze przed fazą hydratacji i dlatego cement nie wykazuje silnej ekspansji oraz można go zakwalifikować, jako bez skurczowy. Wg [19] skurcz po 28 dniach, w środowisku bardzo suchego powietrza wynosi około $0,076 \mathrm{~mm} / \mathrm{m}$, natomiast $\mathrm{w}$ środowisku mokrym ma miejsce pęcznienie, około 0,2 $\mathrm{mm} / \mathrm{m}$ (dla cementów bez skurczowych wg ASTM C 845-96 [1] przyjmuje się skurcz do $0,5 \mathrm{~mm} / \mathrm{m}$ ). Przykładowe przebiegi w czasie skurczu zapraw z cementów Rapid Set ${ }^{\circledR}$ i CEM I ujęto na rys. 3. 


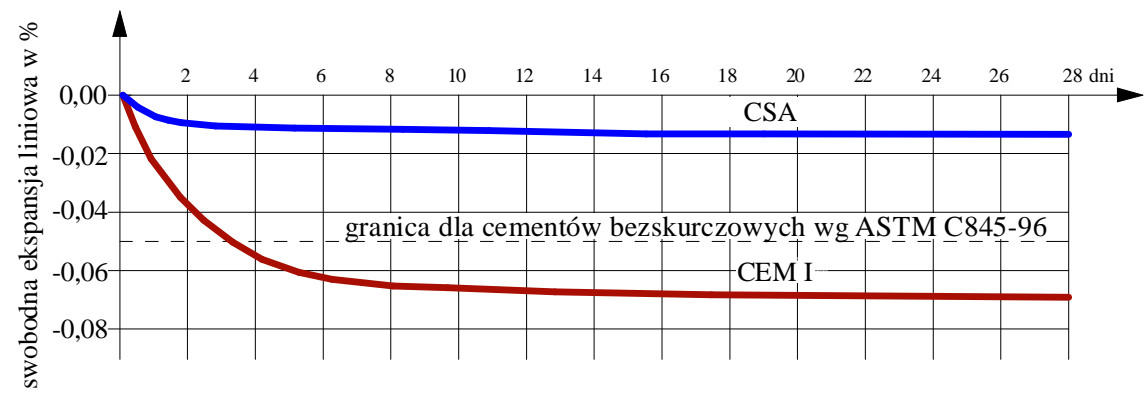

Rys. 3. Przebiegi skurczu w czasie zapraw z cementów Rapid Set ${ }^{\circledR}$ i CEM I

Źródło: Opracowanie na podstawie [4]

Fig. 3. Shrinkage ratios for Rapid Set ${ }^{\circledR}$ and CEM I cements

Source: Based on [4]

\section{Pełzanie według normy PN-EN 1992 Eurokod 2}

Norma PN-EN 1992 Eurokod 2 [11], pełzanie betonu definiuje poprzez bezwymiarowy współczynnik pełzania $\varphi\left(t, t_{\mathrm{o}}\right)$ który można obliczyć na podstawie wzoru:

$$
\varphi\left(t, t_{o}\right)=\varphi_{o} \cdot \beta_{c}\left(t, t_{o}\right)
$$

gdzie:

$\varphi_{\mathrm{o}}$ - stała, zwana podstawowym współczynnikiem pełzania,

$\beta\left(t, t_{o}\right)$ - funkcja zależna od rozwoju pełzania w czasie, określona dla przedziału czasu działania obciążenia $t$ (odpowiadającego okresowi badania pełzania betonu pod obciążeniem) przy rozpoczęciu tego badania po upływie okresu czasu $t_{\mathrm{o}}$ - od chwili zarobienia cementu wodą, do chwili rozpoczęcia obciążenia, inaczej: kiedy wiek betonu wynosi $t_{0}$.

Wartość podstawowego współczynnika pełzania $\varphi_{\mathrm{o}}$ jest zależna od: wilgotności względnej otoczenia $\varphi_{R H}$, wyrażonej w $\%$, współczynnika $\beta\left(f_{c m}\right)$ - zależnego od średniej wytrzymałości 28-dniowej betonu, w MPa i współczynnika $\beta\left(t_{o}\right)$ - zależnego od wieku betonu w chwili obciążenia. Podstawowy współczynnik pełzania, zgodnie z załącznikiem B normy PN-EN 1992 Eurokod 2 [11], oblicza się według wzoru:

$$
\varphi_{o}=\varphi_{R H} \cdot \beta\left(f_{c m}\right) \cdot \beta\left(t_{o}\right)
$$

Współczynnik $\varphi_{R H}$ jest zależny od wilgotności względnej otoczenia i szybkości wysychania betonu, dlatego jest równocześnie powiązany z miarodajnym wymiarem elementu $h_{o}$, w mm, (definiowanym, jako iloraz podwójnego pola przekroju poprzecznego $A_{c}$, do obwodu kontaktu elementu z atmosferą $u$, według wzoru $h_{o}=2 \cdot A_{c}(u)$. Do obliczenia współczynnika $\varphi_{R H}$ służy wzór: 


$$
\varphi_{R H}=\left(1+\frac{1-\frac{R H}{100}}{0,1 \cdot \sqrt[3]{h_{o}}} \cdot \alpha_{1}\right) \cdot \alpha_{2}
$$

Do betonów o wytrzymałości na ściskanie $f_{c m} \leq 35 \mathrm{MPa}$ współczynniki $\alpha_{l}$ i $\alpha_{2}$ są równe 1 , a dla betonów wyższych wytrzymałości, współczynniki są odpowiednio $\alpha_{1}=\left(35 / f_{c m}\right)^{0,7}, \alpha_{2}=\left(35 / f_{c m}\right)^{0,2}$.

Współczynnik $\beta\left(f_{c m}\right)$, zależy jedynie od średniej 28-dniowej wytrzymałości na ściskanie betonu $f_{c m}$ i wynosi:

$$
\beta\left(f_{c m}\right)=\frac{16,8}{\sqrt{f_{c m}}}
$$

Współczynnik $\beta\left(t_{o}\right)$, zależy jedynie od wieku betonu $t_{\mathrm{o}}-\mathrm{w}$ chwili rozpoczęcia obciążenia i wynosi:

$$
\beta\left(t_{o}\right)=\frac{1}{0,1+t_{o}^{0,20}}
$$

Rozwój pełzania w czasie opisuje funkcja, [11]:

$$
\beta_{c}\left(t, t_{o}\right)=\left(\frac{t-t_{o}}{\beta_{H}+t-t_{o}}\right)^{0,3}
$$

gdzie:

$\beta_{H}$ - współczynnik zależny od wilgotności i miarodajnego wymiaru elementu, $\beta_{H}=1,5\left[1+(0,12 R H)^{18}\right] h_{o}+250 \alpha_{3}$, przy czym $\beta_{H} \leq 1500 \alpha_{3}$ oraz dla $f_{c m} \leq 35 \mathrm{MPa}$ wartość $\alpha_{3}=1$, a dla $f_{c m}>35 \mathrm{MPa}$ wartość $\alpha_{3}=\left(35 / f_{\mathrm{cm}}\right)^{0,5}$.

Powyżej przedstawiony sposób obliczenia współczynnika pełzania odnosi się tylko do przypadku początkowego obciążenia nie większego od $0,45 f_{c k}$. Przy przekroczeniu tej wielkości uwzględnia się wpływ nieliniowości pełzania mnożąc współczynnik pełzania przez wielkość exp[1,5( $\left.\left.k_{\sigma}-0,45\right)\right]$, przyjmując $k_{\sigma}=\sigma_{c} l f_{c k}\left(t_{o}\right), g \mathrm{~d} z$ ie $\sigma_{c}$ jest naprężeniem ściskającym, a $f_{c k}\left(t_{o}\right)$ jest średnią wytrzymałością betonu na ściskanie w chwili obciążenia.

\section{Badania wytrzymałości wczesnej na ściskanie betonu z CSA}

Przedmiotem wstępnych badań było określenie odkształceń, związanych z pełzaniem wcześnie obciążonego, młodego betonu na szybkowiążącym cemencie CSA. Do wykonania próbek zastosowano gotową mieszankę Concrete Mix na cemencie Rapid Set ${ }^{\circledR}$ KORODUR (dostępną w Niemczech, w USA, w Polsce i wielu innych krajach, konfekcjonowaną w workach $25 \mathrm{~kg}$ ) o początku wiązania cementu $t_{p w}=32$ minuty. 
Badania wykonano j.w. na mieszance Concrete Mix przy zachowaniu wskaźnika wody do cementu $w / c=0,47$, na 13 -tu próbkach walcowych o średnicy $72 \mathrm{~mm}$ i wysokości $100 \mathrm{~mm}$.

Badania wytrzymałości na ściskanie wykonano na 3-ch próbkach walcowych o średnicach $72 \mathrm{~mm}$ i wysokościach $100 \mathrm{~mm}$ oraz dla porównania wytrzymałości również na 3-ch próbkach sześciennych, o wymiarach $100 \times 100 \times 100 \mathrm{~mm}$, zgodnie z EN 12390-1, [12]. Zgniatanie przeprowadzono po upływie $t_{0}=90$ minut, licząc od chwili zarobienia mieszanki wodą, na prasie Controls Automax5 L0,47, w laboratorium Katedry Geomechaniki Budownictwa i Geotechniki AGH w Krakowie. Na próbkach sześciennych uzyskano średnią wytrzymałość $f_{c m 90}=14,8 \mathrm{MPa}$, a na próbkach walcowych $f_{c m 90 \mathrm{w}}=11,1 \mathrm{MPa}$.

Tabela 1. Odkształcenia pełzania młodego betonu na szybkowiążącym cemencie CSA, o wieku $t_{o}=90$ minut, przy $k_{\sigma}=0,50$

Table 1. Deformation of young concrete creep on CSA rapid cement, age $t_{o}=90$ minutes, with $k_{\sigma}=0,50$

\begin{tabular}{|c|c|c|c|c|c|c|c|}
\hline $\begin{array}{c}\text { Okres czasu działania obciążenia } \\
t, \text { w dniach }\end{array}$ & 1,00 & 2,00 & 3,00 & 4,00 & 5,00 & 6,00 & 7,00 \\
\hline $\begin{array}{c}\text { Odkształcenie pełzania, wg pełzarki 1 } \\
\text { mm x 10 }\end{array}$ & 18,00 & 19,35 & 19,45 & 19,75 & 19,90 & 20,00 & 20,10 \\
\hline $\begin{array}{c}\text { Przyrost odkształcenia pełzania, wg pełzarki 1 } \\
\text { mm x 10 }\end{array}$ & & 1,35 & 0,10 & 0,30 & 0,15 & 0,10 & 0,10 \\
\hline $\begin{array}{c}\text { Odkształcenie pełzania, wg Eurokodu 2 } \\
\text { mm x 10 }\end{array}$ & 12,20 & 15,20 & 17,21 & 18,78 & 20,09 & 21,21 & 22,22 \\
\hline $\begin{array}{c}\text { Przyrost odkształcenia pełzania, wg Eurokodu } \\
\text { mm x 10 }\end{array}$ & & 3,00 & 2,01 & 1,57 & 1,31 & 1,12 & 1,01 \\
\hline $\begin{array}{c}\text { Proporcja wyników } \\
\text { wg wskazań pełzarki 1/wg Eurokodu 2 }\end{array}$ & 1,48 & 1,27 & 1,13 & 1,05 & 0,99 & 0,94 & 0,90 \\
\hline
\end{tabular}

Trzy próbki walcowe o średnicach $72 \mathrm{~mm}$ i wysokościach $100 \mathrm{~mm}$, również po $t_{\mathrm{o}}=90$ minut, od chwili zarobienia mieszanki wodą, zainstalowano w pełzarkach. Kolejne próbki obciążono siłami: 22,5 kN, 18,0 kN, i 13,5 kN, co odpowiadało proporcji naprężenia do wytrzymałości, odpowiednio $k_{\sigma}=0,50$; 0,$40 ; 0,30$. Wartości odkształceń pełzania ujęto w tablicach 1-3 i na rys. 4. Ponadto $\mathrm{w}$ tablicy 4. i na rys. 5. ujęto wartości odkształceń próbki o wieku $t_{\mathrm{o}}=120$ minut, o średniej wytrzymałość $f_{c m 120 \mathrm{w}}=19,5 \mathrm{MPa}$ obciążonej siłą $32 \mathrm{kN}$, tj. przy $k_{\sigma}=0,40$.

Do obliczenia pełzania wg Eurokodu 2 przyjęto obliczoną wcześniej wytrzymałość na ściskanie po 28 dniach $f_{c m}=55 \mathrm{MPa}$, oraz wilgotność powietrza $\mathrm{RH}=50 \%$. Moduł sprężystości, jako początkowy przyjęto $E_{c m}=27 \mathrm{GPa}$, a wiek betonu $t_{o}$ obliczono, jako $1,5 / 24=0,0625$ dnia dla obciążenia po 90 minutach oraz $2 / 24=0,0833$ dla obciążenia po 120 minutach. Obliczenie odkształcenia pełzania wg Eurokodu 2 wykonano programem Mathcad, a wyniki ujęto w tablicach 1 do 4 . 
Tabela 2. Odkształcenia pełzania młodego betonu na szybkowiążącym cemencie CSA, o wieku $t_{o}=90$ minut, przy $k_{\sigma}=0,40$

Table 2. Deformation of young concrete creep on CSA rapid cement, age $t_{o}=90$ minutes, with $k_{\sigma}=0,40$

\begin{tabular}{|c|c|c|c|c|c|c|c|}
\hline $\begin{array}{c}\text { Okres czasu działania obciążenia } \\
t, \text { w dniach }\end{array}$ & 1 & 2 & 3 & 4 & 5 & 6 & 7 \\
\hline $\begin{array}{c}\text { Odkształcenie pełzania, wg pełzarki 2 } \\
\text { mm x 10-2 }\end{array}$ & 7,55 & 8,65 & 8,95 & 9,10 & 9,55 & 9,70 & 9,85 \\
\hline $\begin{array}{c}\text { Przyrost odkształcenia pełzania, wg } \\
\text { pełzarki 2 mm x 10-2 }\end{array}$ & 1,10 & 0,30 & 0,15 & 0,45 & 0,15 & 0,15 \\
\hline $\begin{array}{c}\text { Odkształcenie pełzania, wg Eurokodu 2 } \\
\text { mm x 10 }\end{array}$ & 10,26 & 12,74 & 14,42 & 15,72 & 16,81 & 17,74 & 18,57 \\
\hline $\begin{array}{c}\text { Przyrost odkształcenia pełzania, wg } \\
\text { Eurokodu mm x 10 }\end{array}$ & & 2,48 & 1,68 & 1,3 & 1,09 & 0,93 & 0,83 \\
\hline $\begin{array}{c}\text { Proporcja wyników } \\
\text { wg wskazań pełzarki 2 / wg Eurokodu 2 }\end{array}$ & 0,74 & 0,68 & 0,62 & 0,58 & 0,57 & 0,55 & 0,53 \\
\hline
\end{tabular}

Tabela 3. Odkształcenia pełzania młodego betonu na szybkowiążącym cemencie CSA, o wieku $t_{o}=90$ minut, przy $k_{\sigma}=0,30$

Table 3. Deformation of young concrete creep on CSA rapid cement, age $t_{o}=90$ minutes, with $k_{\sigma}=0,30$

\begin{tabular}{|c|c|c|c|c|c|c|c|}
\hline $\begin{array}{c}\text { Okres czasu działania obciążenia } \\
t, \text { w dniach }\end{array}$ & 1 & 2 & 3 & 4 & 5 & 6 & 7 \\
\hline $\begin{array}{c}\text { Odkształcenie pełzania, wg pełzarki 3 } \\
\text { mm x 10 }\end{array}$ & 6,04 & 6,80 & 7,02 & 7,20 & 7,31 & 7,40 & 7,48 \\
\hline $\begin{array}{c}\text { Przyrost odkształcenia pełzania, wg } \\
\text { pełzarki 3mm x 10-2 }\end{array}$ & 0,76 & 0,22 & 0,19 & 0,11 & 0,09 & 0,08 \\
\hline $\begin{array}{c}\text { Odkształcenie pełzania, wg Eurokodu 2 } \\
\text { mm x 10-2 }\end{array}$ & 7,70 & 9,56 & 10,81 & 11,79 & 12,61 & 13,31 & 13,93 \\
\hline $\begin{array}{c}\text { Przyrost odkształcenia pełzania, } \\
\text { wg Eurokodu 2 mm x 10-2 }\end{array}$ & 1,86 & 1,25 & 0,98 & 0,82 & 0,70 & 0,62 \\
\hline $\begin{array}{c}\text { Proporcja wyników } \\
\text { wg wskazań pełzarki 3/ wg Eurokodu 2 }\end{array}$ & 0,78 & 0,71 & 0,65 & 0,61 & 0,58 & 0,56 & 0,54 \\
\hline
\end{tabular}

Na podstawie badań pełzania próbki młodego betonu na cemencie CSA, o wieku $t_{o}=90$ minut, przy obciążeniu $k_{\sigma}=0,50$, odkształcenia wskazane na pełzarce 1, względem obliczonych wg Eurokodu 2, w pierwszym dniu były około 1,5 razy wyższe i przy wydłużaniu okresu obciążenia proporcja ta zmniejszała się. Około 5 dnia odkształcenia rzeczywiste próbki i wg Eurokodu 2 uległy wyrównaniu, a w 7-mym dniu odkształcenie próbki stanowiło 0,9 wartości normowo obliczonej. 


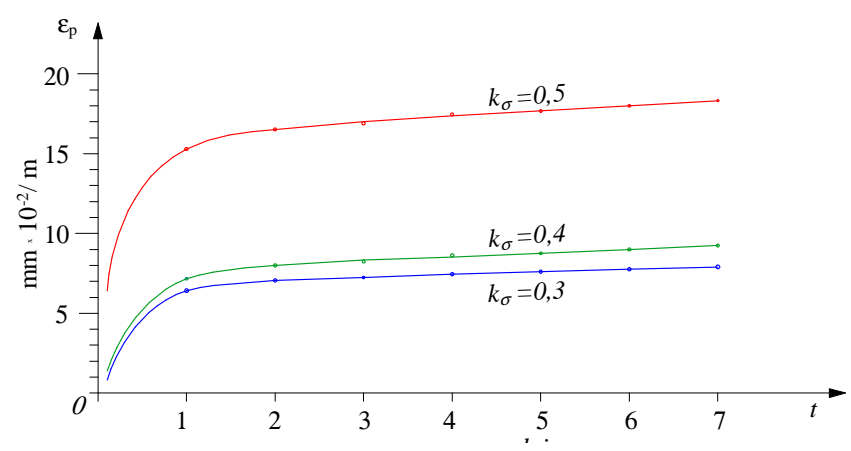

Rys. 4. Wykres odkształcenia pełzania młodego betonu na szybkowiążącym cemencie CSA, o wieku $t_{\mathrm{o}}=90$ minut, przy $k_{\sigma}=0,30 ; 0,4$ i 0,5

Fig. 4. Graph of creep deformation of young concrete on fast-setting cement CSA, age $t_{0}=90$ minutes, with $k_{\sigma}==0.30 ; 0.4$ and 0.5

Tabela 4. Odkształcenia pełzania młodego betonu na szybkowiążącym cemencie CSA, o wieku $t_{o}=120$ minut, przy $k_{\sigma}=0,40$

Table 4. Deformation of young concrete creep on CSA rapid cement, age $t_{o}=120$ minutes, with $k_{\sigma}=0,40$

\begin{tabular}{|c|c|c|c|c|c|c|}
\hline $\begin{array}{c}\text { Okres czasu działania obciążenia } \\
t, \text { w dniach }\end{array}$ & 1 & 3 & 6 & 14 & 28 & 50 \\
\hline $\begin{array}{c}\text { Odkształcenie pełzania, wg pełzarki 4 } \\
\text { mm x 10 }\end{array}$ & 12,50 & 15,25 & 16,25 & 17,45 & 18,42 & 19,60 \\
\hline $\begin{array}{c}\text { Przyrost odkształcenia pełzania, wg pełzarki 4 } \\
\text { mm x 10 }\end{array}$ & & 2,75 & 1,00 & 1,40 & 1,30 & 1,20 \\
\hline $\begin{array}{c}\text { Odkształcenie pełzania, wg Eurokodu 2 } \\
\text { mm x 10 }\end{array}$ & 16,63 & 23,47 & 28,92 & 37,03 & 44,92 & 52,26 \\
\hline $\begin{array}{c}\text { Przyrost odkształcenia pełzania, wg Eurokodu 2 } \\
\text { mm x 10 }\end{array}$ & & 6,84 & 5,45 & 8,11 & 7,89 & 7,34 \\
\hline $\begin{array}{c}\text { Proporcja wyników } \\
\text { wg wskazań pełzarki 4/wg Eurokodu 2 }\end{array}$ & 0,75 & 0,65 & 0,56 & 0,47 & 0,41 & 0,38 \\
\hline
\end{tabular}

Wyniki badań pełzania próbek młodego betonu na cemencie CSA, o wieku $t_{\mathrm{o}}=90$ minut, przy obciążeniach, $k_{\sigma}=0,40$ oraz 0,30 wskazały, że odkształcenia na obydwu pełzarkach 2 i 3 były mniejsze, niż obliczone na podstawie wzorów podanych w normie. W pierwszym dniu odkształcenia stanowiły odpowiednio 0,74 i 0,78 wartości odkształceń obliczonych wg Eurokodu 2 i zmniejszały się, aby po 7-miu dniach wynosić odpowiednio 0,53 i 0,54 wartości normowej.

Wyniki badań pełzania próbek młodego betonu na cemencie CSA, o wieku $t_{\mathrm{o}}=120$ minut, przy obciążeniach, $k_{\sigma}=0,40$ wskazały, że odkształcenia próbki na pełzarce 4 były znacząco mniejsze, niż obliczone wg Eurokodu 2 (rys. 5.). W pierwszym dniu odkształcenia stanowiły 0,75 wartości odkształceń obliczonych wg Eurokodu 2, natomiast po 50-ciu dniach tylko 0,38 obliczonej wartości normowej. 


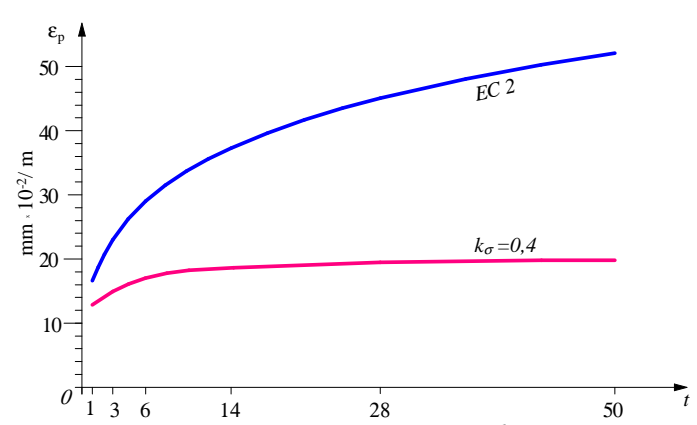

Rys. 5. Wykres odkształcenia pełzania młodego betonu na szybkowiążącym cemencie CSA, o wieku $t_{0}=120$ minut, przy $k_{\sigma}=0,4$ i obliczonego dla tych samych wartości wg Eurokodu 2

Fig. 5. Diagram of creep deformation of young concrete on rapid CSA cement, age $t_{0}=120$ minutes, with $k_{\sigma}=0,4$ and calculated for the same value according to Eurocode 2

\section{Podsumowanie}

Beton na cemencie CSA, opartym o siarczanogliniany wapnia, już po kilkunastu minutach, od zarobienia mieszanki wodą charakteryzuje się bardzo szybko narastającą wytrzymałością, np. po 2 godzinach od zarobienia wodą, $f_{c m 120 \mathrm{w}}>19,5 \mathrm{MPa}$. Stąd taki beton jest predysponowany szczególne do napraw, m.in. posadzek, nawierzchni dróg i lotnisk, również podczas możliwych tylko kilkugodzinnych przerw w eksploatacji.

Zbadane w laboratorium AGH w Krakowie, próbki betonu na szybkowiążącym cemencie CSA, z mieszanki Concrete Mix Rapid Set ${ }^{\circledR}$, już po $t_{\mathrm{o}}=1,5$ godziny, od chwili zarobienia składników wodą, obciążone z zachowaniem wartości $k_{\sigma} \leq 0,45$, charakteryzują się mniejszymi współczynnikami pełzania, niż obliczone normowe wg Eurokodu 2. Należy jednak zauważyć, że w przypadku kiedy obciążenie odpowiada wartości $k_{\sigma}>0,45$, w początkowym okresie badań mają miejsce większe odkształcenia próbek, niż obliczone wg Eurokodu 2. Natomiast przy zwiększaniu okresu czasu działania obciążenia przyrosty odkształceń próbki wyraźnie maleją i np. próbka po okresie 5-ciu dni działania obciążenia, już charakteryzowała się mniejszymi odkształceniami niż obliczone wg normy.

Zatem wstępne wyniki badań pełzania walcowych próbek $(72 \mathrm{~mm} * 100 \mathrm{~mm})$ wykonanych z betonu na szybkowiążącym cemencie CSA, z mieszanki Concrete Mix Rapid Set ${ }^{\circledR}$ dają możliwość obciążenia tego betonu już po godzinie od zarobienia mieszanki wodą, ale konieczne jest potwierdzenie uzyskanych wyników na normowych próbkach walcowych $150 * 300 \mathrm{~mm}$. 


\section{Literatura}

[1] ASTM C 845-96. Standard specification for expansive hydraulic cement.

[2] Bryła S. „Zachowanie się betonów glinowych pod wpływem czynników zewnętrznych” Inżynieria i Budownictwo 2,3 1938.

[3] Klein A. Expansive and shrinkage-compensated cements" Patent US3, 251701

[4] Korodur International GmbH. Product Information.

[5] Jamroży Z. Beton i jego technologie, Wydawnictwo Naukowe PWN SA, Warszawa. 2015.

[6] Kurdowski W. Chemia cementu i betonu. Stowarzyszenie Producentów Cementu. Kraków. 2010.

[7] Neville A.M. „Właściwości betonu” Stowarzyszenie Producentów Cementu, Kraków 2012.

[8] Nocuń-Wczelik W., Konik Z., Stok A., Małolepszy J. „Spoiwa o kontrolowanych zmianach objętości do prac naprawczych i uszczelniających" XXIV Konferencja Naukowo-Techniczna Szczecin-Międzyzdroje, 26-29 maja 2009.

[9] Nocuń-Wczelik W. „Cement. Metody badań. Wybrane kierunki stosowania” Wydawnictwo AGH Kraków 2015.

[10] Mitzel A. Reologia betonu. Arkady Warszawa 1972.

[11]PN-EN 1992 : 2008 Eurokod 2 Projektowanie konstrukcji z betonu.

[12]PN-EN 12390-1 Beton. Część 1: Kształt, wymiary i inne wymagania dotyczące próbek do badania i form.

[13]PN-EN 206-04:2014 Beton. Wymagania, właściwości, produkcja i zgodność.

[14] Więckowski A. Hajto D., Marcinkiewicz K. Zimka R. Wytrzymałość wczesna na ściskanie betonów z CSA w zależności od w/c Zimowa Szkoła Mechaniki Górotworu Wisła 2016.

[15] Rüsch H., Jungwirth D. Skurcz i pełzanie w konstrukcjach betonowych. Arkady 1979.

[16] www.concretecountertopinstitute.com/csa-cements-rapid-strength-with-a-lowcarbon-footprint/ The Concrete Countertop Institute.

[17] www.bluey.com.au/wp-content/uploads/2012/03/BluCem-CSA-Cem-LR-R2.pdf Bluey CSA Cement. Product Information.

[18] www.csa-cement.com Polar Bear CSA Cement. Product Information.

[19] www.csacement.com Oreworld Cement Manufactured. Product Information.

[20] www.buzziunicemusa.com/docs/cement/csa_cement.aspx CSA Cement by Buzzi Unicem, Bethlehem USA. Product Information.

[21] www.concretecountertopinstitute.com/csa-cements-rapid-strength-with-a-lowcarbon-footprint/ The Concrete Countertop Institute. Product Information. 


\section{STRAIN OF EARLY LOADED YOUNG CONCRETE ON FAST- SETTING CSA CEMENT}

\section{S u m m a r y}

CSA is mineral, hydraulic, fast-setting binder of low shrinkage and high sulphate resistance. Once the CSA cement has been treated with water, a rapid reaction occurs between calcium sulphate, gypsum and calcium hydroxide, with dynamic heat generation and intensive ettringite, a mineral that achieves high early strength. Rapid growth of CSA concrete strength (several MPa, 1 hour after adding water) enables early loading of elements. Thus, the subject of preliminary research was to determine the size of deformation occurring in young concrete, with the working load, after 1.5 hours and 2 hours after the ingredients were mixed with water. In the context of the results of Eurocode 2 calculations it was found that the deformation of young concrete samples on CSA in case of loads $k_{\sigma} \leq 0.45$ are not higher than those calculated on the basis of the norms enclosed in the standard. For larger loads, at $k_{\sigma}>0.5$, for non-linear creep calculations, deformation after the first day exceeds theoretical values by about $50 \%$, and in subsequent days it decreases. After 5 days the deformation is lower than that calculated according to Eurocode 2.

Keywords: calcium sulfoaluminate cement, CSA, creep of concrete, rapid concrete

Przestano do redakcji: $24.05 .2017 \mathrm{r}$.

Przyjęto do druku: 01.09.2017 r. 